\title{
THE ROLE OF THE LABOUR DEPARTMENT IN THE BIRTH OF AFRICAN TRADE UNIONISM IN NORTHERN RHODESIA ${ }^{1}$
}

\begin{abstract}
It would be deplorable if an alien spirit were introduced into this property in pursuit of an ideological end which may prove of no benefit to the mining companies, the African employees, your administration or Broken Hill as a whole. ${ }^{2}$
\end{abstract}

Where possible, European minorities in Africa during this century have sought to insure their favored position, especially their economic position, through political action. The trend of labor legislation in Southern Rhodesia after it became a "self-governing Colony" in 1923 is a case in point. But this was not always possible. In Northern Rhodesia, for instance, the color bar was far more difficult to introduce, especially after Lord Passfield's 1929 revival of the native paramountcy doctrine for east and central Africa. The history of the white miners' trade union is apposite.

It must, however, be considered in the curious context of Northern Rhodesian life during the harrowing 1930's when the purpose for which many men had journeyed to the Protectorate ceased to figure.

\footnotetext{
1 Materials for this essay are taken from the Northern Rhodesia Archives in Lusaka. I was fortunate enough to be given permission to view materials within the "50 year rule" in both (then) Northern Rhodesia and Nyasaland in $196 x$ and again in 1963 . The Archivist for Northern Rhodesia, Mr. Ivar Graham, a charming and able man, quickly explained the system to me and throughout did what he could to aid my enterprise. The Zambia Government is, unlike many successor regimes, in possession of an admirably organized and extensive archive. Most of my materials came from two sources, the files of the Secretary for Native Affairs and the Department of Labour, i.e. from Secretariat rather than "Provincial Administration (P.A.)" records. Those citations which do not refer to a Sec./ Lab. or a Sec./Nat., such as Acc. 52/17, are simply accession materials not recorded in other ways as yet. Those who are familiar with the building which houses the Archives will agree that it is perhaps the most attractive, as well as rationally designed, structure in tropical Africa devoted to such purposes. - Much of the material was available to me through the kindness of various departmental officials. I wish to thank Mr. Roy Philpott, at present Permanent Secretary, Ministry of Labour, especially.

2 The quote is taken from a letter which the general manager of the Broken Hill mine, Mr. T. R. Pickard, wrote on 6 April r948. See Sec./Lab./125.
} 
Colonial Office attitudes, and indeed general European attitudes, must be surveyed on both sides of the momentous decision to go ahead with the exploitation of the copper fields. Until that time Northern Rhodesia was known, rightly, as a poor dependency, a drag on the more likely southern colony; after the preliminary work began, attitudes necessarily changed. By the time of the Second World War, when copper evidently was king, a good many earlier views of the proper relations between subject peoples and colonizers had disappeared. Put simply, there were sound reasons for inducing whites to bring their skills to the copperbelt, there were explanations for these persons having secured their position, and all this despite the ostensible responsibility of London trusteeship. In Southern Rhodesia white workers at a very early date had secured privileges for themselves and their progeny, but that, after all, was a "white man's country". Even in Kenya, where a smaller number from generally better circumstances had pressed for permanency of tenure, at least in the "white (note the reiteration) highlands", this seemed to be a possibility.

But, in Northern Rhodesia, a country where medical authorities presumed European children could not flourish, and the possibility of significant white immigration appeared slight, very few really believed in a perpetual white presence. But, the belief gained credence from the middle 1930's when the revived copper mining industry encouraged many Europeans who had starved through the lean years. It would be easy to explain the increasingly racist tone of settler utterance by reference to the expanding South African population, but it would not interpret this phenomenon, at least not sufficiently for serious students. To a degree, the vocabulary of fascism spilled over into even these remote territories; to a greater extent the democratic states talked about the necessity of colonies and the obligations of trusteeship. In all cases the remembrance of total collapse, of catastrophic unemployment, drove men to bulwark themselves against a recurrence of disaster. One could repudiate the label of racist, then, while at the same time advocate a "white only" system which appeared to be based on "civilized" standards."

In 1936 , to the consternation of Government and mining management, the press reported that the white South African Mineworkers' Union was prepared to establish copperbelt branches and incorporate the first Northern Rhodesian union, the somewhat shadowy Industrial Workers' Federation. Curiously, the notion got about that the South

${ }^{1}$ Cf. my article "The African Worker in Southern Rhodesia: Black Aspirations in a White Economy, 1927-36", in: Race, Oct. 1964. 
Africans intended establishing African unions. This misapprehension corrected, the companies asked for Colonial Office comment and were assured that South African racial policies would not be tolerated in the Protectorate. Some officials hoped that the British Trades Union Congress, which at least officially shared this repugnance for industrial racialism, might come out against the idea also.

When the general secretary of the South African Mineworkers' Union met the Protectorate's Governor Sir Hubert Young, he was told about this anti-color bar policy. Or, so Sir Hubert said. His auditor, Mr. Charles Harris, discounted this news, apparently because he thought the Governor in reality approved the formation of white unions. He knew that company managers did. ${ }^{1}$

Apart from Mr. R. Olds, the miner husband of an elected member of Legislative Council, Harris received the most help from the Railwaymen, who as an inter-territorial body reflected the views of Southern Rhodesian unionists. This industry alone in Northern Rhodesia had an acknowledged color bar. Other Europeans did not possess the economic leverage, an example being the Building Artisans' Trade Union, which in 1933 had been unable to enforce its demand for an all-white policy on Government undertakings. So, too, various official functions were performed by Africans, as any South African who visited a Protectorate Post Office could testify.

In the event, Harris was unsuccessful. The reasons for his failure are obscure, though he later referred to false charges levied against him by unspecified persons. ${ }^{2}$ Evidently, he discovered that his union could not organize foreign branches, and at the same time he seems to have become embroiled in a local dispute centering on his sponsor, Mr. Olds. Government and the companies assumed that the threat was past, in which judgment they were wrong, for on 25 October a union with a constitution identical in all ways with that of Harris's South African Mineworkers' Union was organized at Luanshya, styling itself the Northern Rhodesian Mineworkers' Union. ${ }^{3}$ Within

${ }^{1}$ See Rhodesia Herald (Salisbury), 9 June 1936. The best definition of color bar I have encountered, is supplied by W. J. Busschau in his Report on the Development of Secondary Industry in Northern Rhodesia (Typescript, Lusaka, 7 January 1945), paras 4I and 44: "The colour bar may be defined as a process whereunder the African workers are prevented from (1) acquiring skill, (2) exercising skill and (3) obtaining the full reward for the exercise of skill. It may operate through agreement, custom or law and may consist of any combination of the three elements in the definition... The effect of colour bar arrangements is to decrease the supply of skilled labour and to increase the supply of unskilled labour as compared with the supply of both types of labour that would be forthcoming in the absence of such arrangements."

2 Bulawayo Chronicle, is January 1938.

' It should be borne in mind that the ratio of white to black workers was about I : 20 . 
a year it was reorganized, and from that time pressed for a color bar along the lines of the Southern Rhodesian Industrial Conciliation Act of 1934. Lord Hailey, noting this tendency, argued that it would embarrass the Colonial Office without effecting its purpose, for copper was subject to the vagaries of a world market." "They have this system in the building trade in Salisbury", one critic explained. "It is, needless to say, quite effectual in keeping out native competition in any job which the European claims for himself - anything that does not involve hard manual labour."'

Trade unions suggested the timeliness of a northern Labor party. By 1938, there was the hint of an inter-territorial grouping, which could press for a Southern Rhodesian solution. Most colonial trade unionists believed that a Labor party would protect their interests. As one contributor to the Rhodesia Railway Review put it, the best way to prevent the upgrading of African employees on the copperbelt was to form "a strong Labour party there..."3 The war was useful for this purpose. In I94 I, the rising trade unionist and politician, Mr. Roy Welensky, articulated a Labor as opposed to a settler interest, and established the Northern Rhodesian Labour Party. He was in a strong position, for workers were in short supply and the Imperial Government urged maximum copper production, telling the companies to buy industrial peace for the duration of the conflict. So fearful of offending white labor was Government, that the question of "diluting" entrenched white positions with black workmen was shelved. Instead, the Southern Rhodesian approach was adopted, where white women replaced some white men and everyone drew overtime bonus.

Moreover, in recognition of their special role, a representative of European unions was suggested for appointment to the Native Industrial Labour Advisory Board, in I941 renamed the African Labour Advisory Board. Mr. Harry Franklin, a man of great administrative experience, who made this motion, argued that the white unionist was "more closely concerned than any other European with

\footnotetext{
1 Malcolm, Baron Hailey, Native Administration and Political Development in British Tropical Africa, 1940-42 (Confidential), pp. $281-82$.

${ }^{2}$ (Salisbury Archives) RA I/I/1. Henry Rangeley to Mr. (now Sir) Andrew Cohen of the Colonial Office. Cholo, Nyasaland, March 1938.

${ }^{8}$ Rhodesia Railway Review, June r94r. See Julius Lewin's prophetic pamphlet, The Colour Bar in the Copperbelt (South African Institute of Race Relations, 1941), based on his May 1940 trip. In the case of Nyasaland the situation was even more delicate, for there some saw Welensky's party as a potential threat to native paramountcy in the lake Protectorate, too. See the Anglican Bishop's challenge to Welensky for a statement on color bar in Sec./Nat./92, clippings from Nyasaland Times of 27 December 1941 and 8 January 1942.
} 
the general handling of native labour". ${ }^{1}$ No doubt this was a recommendation, but it also delineated the peculiar position of the white "worker" in central Africa. His proposal was approved by the Labor Commissioner, Mr. R. S. Hudson, who fancied anything "designed to keep European workers more in touch with African workers and their problems", but the Governor, in response to an objection raised by the member for Railway interests, turned down the suggestion. $^{2}$

Meanwhile, the miners had secured a union shop agreement with the copper companies, who later alleged that they gave in to a strike threat and Government pressure. ${ }^{3}$ Whatever the explanation, in 1942, the union also obtained agreement on an inserted "clause 42 ", by which management reserved enumerated jobs for those eligible when the original contract had been signed. Since potential union members were the only eligible workers, and since the union was open only to Europeans, the miners' argument that the clause was designed merely to prevent "dilution of labor" looked disingenuous."

By 194I, observers within the Labour Department were convinced that Africans already could replace large numbers of European workers. Labor Commissioner Hudson estimated that almost all surface jobs and perhaps half of those underground could be done by Africans, without acknowledgment. That Africans would press for "extension of opportunity", the current euphemism for circumvention of the color bar, seemed evident. ${ }^{5}$ If, as some black miners claimed, the whites had jeered at them during the 1940 strike, taunting the "monkeys" with an inability to organize, the opportunities for this sort of contempt were becoming rarer. Never again were whites quite so confident of their superiority. In a sense, the 194I agreement which the Europeans wrested from the companies responded to a 1940 African demand for a racially-organized production contest. ${ }^{6}$

"Franklin was an "official" member, i.e. a Government official appointed to the Board, not a representative of the "settler" community. The Board was advisory only, though its representations usually went to the Executive Council. It theoretically represented all interests dealing with labor matters, all that is except the Africans themselves.

2 Sec./Lab./33, 26 August, 4 September and I November 194I.

${ }^{3}$ Report of the Commission Appointed to Inquire into the Unrest in the Mining Industry in Northern Rhodesia, 1956. Paragraph 37 of Appendix (Management Case). Hereafter, the Branigan Report.

'EA 5I, Vol. I, Hudson's diary, r7024 November I94I. Clause 42 is discussed in the I95I agreement in Box $421, \mathrm{Hb} / 6_{3}$.

${ }^{5}$ EA 5i, Vol. I, 25-30 August 194I.

${ }^{6}$ Box $421, \mathrm{H} / 22$, report by G. Howe dated 29 April 1940, p. 27. Also Sec./Lab./137 for interviews with striking Africans. A decade later the Central African Post editorialized: "We have been told by Europeans employed on the mines and railways that Africans do 
To recognize African impatience was one thing, to abet it another, and Commissioner Hudson was not prepared to go so far so fast. When he visited South Africa later in the year, and was asked by African trade unionists whether there would be any objection to their organizing on the copperbelt, he replied that it was too soon for such a course. Even two years later, when conditions had changed considerably, Hudson remained suspicious of South African overtures, wondering whether the Cement Workers, who had requested information about Northern Rhodesian conditions, were "bona fide or under the influence of our gallant allies the Communists". ${ }^{1}$

The last pre-war word on labor matters had been said by Major G.St.J. Orde Browne, ${ }^{2}$ who called for at least four Labor Officers, but by 1941 , a year after the second African miners' strike involving fatalities, only one was established. Nor was there general agreement on his role. The District Commissioners were uncertain of their relations with him and his Commissioner, but the Secretary for Native Affairs thought an analysis should be postponed. Meanwhile, the Labor Officer "could in a sense carry out the functions of a shop steward" and "together with Tribal Representatives be in effect the native labour trade union". This interesting suggestion implied that Labor Officers would minimize their official status, which in turn suggested something less than complete identification of interests with those of the District Commissioners, who would remain the symbols of state. Commissioners, he believed, should not attend meetings with tribal representatives, but instead should promulgate their views through the recently formed native urban advisory councils. ${ }^{3}$

so little work to justify their employment, and yet when they strike, work is paralysed to an astonishing degree." I I January $195 \mathrm{I}$.

${ }^{1}$ Box $42 \mathrm{r}, \mathrm{Hb} / 63 ; \mathrm{J} 4 / 52 / 20,9$ November 1943. For the possibility of communist penctration, see the tantalizing letter which Mr. A. Royden Harrison, manager of the Rhokana Corporation, wrote the Chief Secretary early in May 1942, enclosing a clipping from the (South African) Guardian of 2 April. An anonymous correspondent described the manner in which Africans were denied trade unions in Northern Rhodesia: "Try to start a trade union among the African workers on the copper mines, and see how long you keep the job! Tell the workets how much they have to gain by organization - and see how long you are allowed to remain on the Rhodesian side of the border!" The writer was perhaps "one John Victor Daniel, who was persuaded to leave this territory last December, as he was regarded as a potential agitator, as he wished to form a native trade union at Luanshya". Sec./Misc./73, 23 April 1942.

${ }^{2}$ Major Orde Browne was the Colonial Office expert on tropical labor. He was the author of the report for Northern Rhodesia, as well as others, including one done on education in French Africa.

${ }^{3}$ In Northern Rhodesia, industrialization early produced a class of African employees called tribal elders, which was supposed to mediate between labor and management, that 
Labor Commissioner Hudson accepted the guiding role which Sir John Forster's report on the I940 African strike had assigned his department, feeling certain that by doing so Labor Officers would help "avoid serious discontent and industrial unrest on the part of the native workers". Hudson agreed that loudspeakers placed in compounds and pronouncements at the meetings of the urban advisory councils would be sufficient to spread Government news, but he did not understand why District Commissioners should be barred from meeting with tribal elders. His view persuaded the Governor. ${ }^{1}$ The District Commissioners of the Western Province "agreed that for some years the tribal representatives would not be able to differentiate between matters political, economic, social and industrial and they would be in doubt as to whom to approach, unless all parties worked in cooperation". ${ }^{2}$

By this time, the elders were under fire from Africans and Europeans alike. At Mufulira during the violent 1940 strike the workers had rejected their elders, and genuine spokesmen, the fascinating yet obscure "committee of $x 7$ ", had appeared. This had encouraged the creation of elected "tribal representatives" there and on the Roan Antelope mine. By late I94I, a novel system of tribal proportional representation had been devised at the Nkana mine, where those elected met monthly with the compound manager and the labor officer. They were "working men and not clerks or police or others

$i_{s}$ to say between the governed blacks and the governing whites. Within a year of actual production at the Roan Antelope mine these persons were noticed on the copperbelt, and while subsequent closures halted the experiment, by 1936 there was agreement that "elders in compounds should be part and parcel of the compound organisation and be dependent on the compound manager". The first compound manager at Roan Antelope mine had argued for a council of tribal elders functioning as a "workmen's committee" until it withered away before the inroads of "detribalization".

Nat./M/13, 9 December 1932 ; also memo by Mr. H. L. Brigham in Ja/17; Sec./Lab./34. Report of subcommittee of the Native Industrial Labour Advisory Board; Sec./Nat./4, I9 January 1942; Spearpoint's article in the supplement to the Journal of the Royal African Society (1937); W./6/28, 10 March 194I; also see G. St. J. Orde Browne, Labour Conditions in Northern Rhodesia (Colonial Office I 50 of 1938) for a statement of the position shortly before the war; and Acc. 52/18, 13 May I94I.

I Ibid., 3 December 1941.

2 Acc. 52/17, 3 July r 941; Sec./Nat./4, Kitwe, August 1941. An examination of the names of leaders, even in the variant spellings of police reports, demonstrates that very often the same person figured in a welfare association, an advisory committee, a boss-boys' group and even an elders' committee. Considering the paucity of literate persons it is surprising that simony was not more prevalent. It was charged by Europeans that these men entered such groups for self-advancement; I should think rather that these bodies offered liberation for so many village Hampdens, who were quite prepared to espouse various causes with equal enthusiasm. 
in authority unacquainted with the life of the average man". ${ }^{1}$ The Nkana system had been accepted tentatively by the Chamber of Mines on the recommendation of the Forster Commission. Appointed representatives remained at Nchanga. The Mufulira approach had gained the admiration of South African Senator J. D. Rheinallt Jones, who toured the mines that year. He thought these men might have a useful quasi-union role.

However, they did not live up to the Senator's expectations. In some cases, elders simply became representatives through the customary exercise of tribal prestige, and in many instances the representatives appeared more interested in the perquisites of office than in the presentation of claims. "Boss boys", those skilled foremen assistants, resented placing their often technical complaints in the hands of less knowledgeable men, and began to display an interest in presenting their own grievances. ${ }^{2}$ The Labor Officer at Mufulira concluded by mid-I 942 that "it would probably be much better to allow them to form their own association and to have it officially recognised by the managements". His Commissioner was quick to note the significance of this development of occupational groupings. "We certainly should not suppress any desire on the part of any class to express its grievances and should guide any tendencies towards associations." 3 Certainly, whatever diminished tribalism seemed a good thing to many. The Anti-Slavery and Aborigines Protection Society, for instance, pointed out the undesirable aspects of tribal voting, as practised at Nkana, and called upon the Labor Department to "encourage Africans to experiment in the particular form of industrial association best suited to their needs and to give them definite training in the business methods required..."4

The tribal representative was the model some boss boys chose, unfortunately. At Mufulira, for example, they asked for house lights, better housing and money gifts at Christmas, things normally reserved for tribal representatives. ${ }^{5}$ Aware of their increasing importance, early in 1942 they informed the Labor Officer that "all kinds of mine employees came to them with their labour troubles and that when representatives spoke to us, we should realize the things they asked

\footnotetext{
1 Sec./Lab./45, Vol. I, Nkana inspection, 12-14 November 1941.

${ }^{2}$ Sec./Lab./45, Roan Antelope mine, July 1942; Ibid., Mufulira, July I 942. Memorandum on Racial and other Aspects of the Industrial Conditions on the Copperbelt (South African Institute of Race Relations, 20 April 1942).

3 Ibid., Roan Antelope, 19-21 November 194I, Mufulira, February 1942.

4 Memorandum on the Forster Commission Report (September 194I). Report cited as Report of Commission Appointed to Inquire into Disturbances... (Lusaka, I940).

${ }^{5}$ Sec./Lab./45, March 1943.
} 
for affected others as well". The Labor Commissioner told the Labor Officer to continue shuttling all complaints not specifically concerning boss boys to the tribal representatives. ${ }^{1}$

Complaints affecting boss boys certainly did affect other African workers. The perennial grievance was assault, an unfortunately large number of white workers tending to enforce their orders with blows and oaths. One minor complaint suggests a good deal about conditions on the mines 20 years ago. The Luanshya boss boys wondered if it were not silly to remove headgear when addressed by company officials underground. ${ }^{2}$

Even those who had been certified up to European standards of proficiency (as 32 were in March I 943 at Nkana), were troubled by white foremen who disliked having orders refused on safety grounds. ${ }^{3}$ Boss boys' dissatisfaction was so apparent at Luanshya that by September 1943 the Labor Officer thought a general meeting should be convened, so that they might again be cautioned about their limited importance. He feared a tendency for their organization "to develop into a semi-political grouse committee run in opposition to the tribal representatives..."4

In September 1942, Labor Commissioner Hudson had asked the secretary of the Chamber of Mines whether the companies would allow Labor Officers to see boss boys separately; also, whether the same permission might be extended to clerks, should they too reveal separatist tendencies. After some hesitation, agreement was reached, and early in October Labor Officer Stubbs met with the boss boys of Nkana mine. ${ }^{5}$ Labor Officer Shaw encountered opposition at Mufulira, which led him to invite the compound manager to attend his first meetings "to allow the suspicion of our motives entertained by this company to subside somewhat". 6 At Nchanga the men were slow to organize, perhaps because the work force was smaller, more likely because the tribal representatives were doing their job; certainly they were independent of the compound manager "in that they receive no 'perks' from the company as elsewhere".?

${ }^{1}$ Ibid., Nkana, Mindolo, 22-5 March 1943. For an early European miners' union view of boss boys, see Acc. 52-I 8 for notes taken 2 October 1942.

${ }^{3}$ Sec./Lab./45. Luanshya, July and August 1943. See Box $2758 \mathrm{~h} / 26$ for a complete file devoted to racial fights on the mines.

${ }^{3}$ Sec./Lab./45, Mufulira, April 1943.

${ }^{4}$ Ibid., September 1943.

${ }^{5}$ Acc./52/18, 9 September 1942 ; Sec./Lab./45, Nkana and Mindolo, 5 October 1942.

- Ibid, October r 942.

'Ibid., Nchanga, 5-9 December 1942. The tone of business community comment was sounded most authentically somewhat later by the Rhodesia Railways. "The African labour situation in both Rhodesias can be regarded only with grave concern. Communistic 
If in 194I Europeans were trying to block African advances, by 1942 they were ousting them from jobs, with the intention of securing work for a second generation of white miners. The Labor Commissioner wrote that a strong miners' union "has acted to the detriment of African semi-skilled workers", but conceded that nothing much could be done: "it is a difficult problem to tackle in war time." He ordered Labor Officers to record further instances of this trend "unobtrusively". ${ }^{1}$ It was small comfort to learn that the same problems vexed Katangese authorities, too. A Northern Rhodesian official was told by M. Rollus, Head of the Department of Native Labor, that Congoborn Belgians seemed "naturally antagonistic towards the native".2

This racial discord was heightened in late 1943, when a most circumstantial rumor, to the effect that a British trade unionist would be dispatched by the Colonial Office to organize copperbelt Africans, agitated the European community. This news supposedly had been picked up on the BBC's signal. Though Government denied such intentions, the story was sufficiently worrisome to stir the miners into a consideration of Jim Crow branches. "What the committee had in mind to recommend to the Executive was the development of an African trade union parallel to the European union but submitting matters to and controlled by the Central Executive which should be European, as at present." The Labor Commissioner thanked Mr. Goodwin, the miners' president (and later Member of the Legislative Council), but since Africans were not ready for unionism felt that his efforts, though well-intended, were premature. ${ }^{3}$

The committee which Goodwin referred to had been formed in August in a meeting of about 60 men at the Roan Antelope mine. That they moved with the times is suggested by the editorial approval of guided African unionism registered in the Bulawayo Cbronicle and the Northern News. ${ }^{4}$ Some officials, though, were not prepared to concede an altruistic purpose. Mr. Cartmel Robinson, the Provincial Commissioner, Western Province, thought perhaps the "union does

elements are increasingly influencing subversive activities among the politically immature African leaders,..." General Manager's Report for the Year Ending 30 September 1947 (Bulawayo, I May 1948).

1 Sec./Lab./45, 12 February 1942.

${ }^{2}$ Sec./Lab./48. For an excellent discussion of Congolese developments in this period, see Jean Ryckbost, "Essai sur les origines et le développement des premières associations professionnelles au Congo (1940-44)", Université Lovanium, Institut des recherches économiques et sociales (IRES), February 1962.

${ }^{3} \mathrm{Sec} . / \mathrm{Lab} . / 34$, I October 1943.

$4 \mathrm{~J}$ 4/52/20, I 8 August 1943; Bulawayo Chronicle, 27 August and Northetn News, I September 1943 . 
not wish Government to take seriously their idea of organizing Africans. It would suit their book... to blame Government for frustrating their intentions. Probably they wish to put themselves in the good books of the Trade Union movement overseas."1 On the other hand, Labor Officer Stubbs believed in Goodwin's sincerity, which seemed grounded on practical assumptions about the greater productivity of a contented work force. ${ }^{2}$

Goodwin had deplored a certain woolliness in the thinking of British Labour Party leaders, none of whom understood African conditions, yet he agreed with them in condemning the pittance earned by African laborers. To forestall Chamber of Mines efforts to hamper organizational work, Goodwin asked whether union representatives might attend meetings of Tribal Representatives and "boss boys", the two semi-official bodies which expressed African opinion on the mines. And in another connection he queried why his union was not on the African Labor Advisory Board, a revival of Harry Franklin's idea. Goodwin especially wanted to see a copy of a working paper drafted by a South African sociologist, Mr. Ambrose Lynn Saffery, who had been hired as an industrial adviser to Government. On both matters, the Labor Commissioner avoided direct refusals. ${ }^{3}$

Whereas Mr. Welensky was arguing that the white miners should be encouraged to go ahead till it was too late for their rank and file to compel a retreat, Commissioner Hudson believed Government should publicise what he took to be its guiding role. Hudson seems to have felt that any non-Governmental encouragement or assistance would be undesirable for African miners.

In fact, nothing was done by anyone. In June 1945, the Labor Officer at Kitwe reported Goodwin's intention to organize "machine boys", a class of laborers skilled in all but name, but again nothing came of it. Though by war's end Government had begun to worry about the unlikely danger posed by an African work force controlled by militant white socialists, in 1947 one official concluded that the white miners only raised the threat of black unionism when new wage demands were in the air. ${ }^{4}$

It was odd, but true, that in certain respects the much smaller white populace of Northern Rhodesia seemed more capable of bullying the colonial regime than were Southern Rhodesians. In 1946, the European miners forced the companies to retain "clause 42 "

${ }^{1}$ Sec./Misc./67, 6 September 1943.

${ }^{2} \mathrm{~J} 4 / 52 / 20,15$ September and 24 October 1943.

${ }^{3}$ Sec./Lab./34, I October 1943.

${ }_{4}^{4}$ Acc. 52/1 8, 30 August 1945; J 4/52/20, 24 November 1947. 
and tried to enlist the support of Africans during a strike to enforce European demands. ${ }^{1}$

That the white miners increasingly were isolated from their fellow workers in Europe, was suggested by Welensky's condemnation of their "equal pay for equal work" gambit when he visited London during the spring of $1946 .{ }^{2} \mathrm{He}$ contrasted the miners' organization unfavorably with his own, the Railway Workers' Union, which advocated affiliation of black workers, recognizing that European standards could be preserved only if Africans came to adopt them. True, Welensky probably did not imagine an immediate African ascent to commanding heights, but he at least considered the possibility, whereas the miners' president a decade later, speaking of racially-integrated undertakings, still thought "no one knows when it will come about". 3

Not for some time of course had the miners enjoyed British trade union support, a fact they rediscovered whenever racial conflict was reported in the United Kingdom press. In 1948 , they asked the British TUC to support them in their proposal to enlist black affiliates, but were told that they first had to satisfy the TUC on certain matters raised by Northern Rhodesia Government. ${ }^{4}$ Criticism by organizations such as the Movement for Colonial Freedom in itself was no disgrace perhaps, but even this organization expressed a genuine British sentiment when it reminded the copperbelt miners that "the interests of trade unionists and the working class in general are identical - internationally and inter-racially". ${ }^{5}$ To understand how the African portion of these interests was articulated in the late 1940's, we now must examine the wartime role of the Labour Department more closely.

Where workers were slow to develop any urge for representation, officials gradually presumed a necessity for implanting the notion. When a sudden strike paralyzed the Zambezi Saw Mills in January I943, the Provincial Commissioner remarked that the strikers "are doing exactly as was done on the copperbelt (in I940): they say they want more pay, they will not talk to anybody, they will not listen to anybody and when it comes to the point they do not know what they want..." He felt the time had come "to force these people to have some sort of native organisation to represent them". ${ }^{6}$ Belatedly, the company agreed and $\mathbf{2} 2$ representatives were elected by the workers.

${ }_{1}$ Acc. 52/18, 17 September 1946 and Branigan Report (1957), paragraph 37.

${ }^{2}$ United Empire. The Journal of the Royal Empire Society, Vol. 37 (1946), pp. 236-40.

${ }^{3}$ Northern News, 5 June 1956 . The then president was Mr. Jack Purvis, of recent years an Africa specialist for the International Confederation of Free Trade Unions.

$4 \mathrm{~J} 4 / 52 / 20,4$ June 1948.

${ }^{5}$ Box $432 . \mathrm{N} / 2709 / 4,6$ January 1955 (also released to London press).

- Box 43 O. Hi 2, Vol. I, diary of strike, I2-1 3 January 1943. 
Only a month earlier, when Labor Officer Roy Philpott had suggested this, the company had worried lest such men might become a strike committee, and insisted that in any case their compound manager kept in close touch with the workers, who were conservative Lozi, controlled by the will of their paramount chief. ${ }^{1}$

Here, too, tribal representatives soon fell into disrepute. During a quick and abortive second strike early in 1945 , the men refused to let their representatives act. Philpott, who reported this incident, was told that the same thing had occurred on the copperbelt; it did not invalidate the system, though it did suggest the need for some procedural advice on his part. ${ }^{2}$

Despite the Labour Department's (and this article's) concentration on their problems, mineworkers were not the first Africans to become interested in true industrial combination. Rather, the shop assistants at Mufulira first thought of trade unionism as a way out of their difficulties. In $\mathrm{I}^{942}$, it was common for shopkeepers to discharge them just short of a year's employment, thereby allowing the merchants to avoid certain obligations, such as leave pay. The Labor Officer, noting this, predicted a shop assistants' union, which the Labor Commissioner thought might be a useful development. ${ }^{3}$ Soon after, the assistants decided to form a committee of four to build a union, but the urban advisory council ${ }^{4}$ resented this development. With Labor Department supervision, the conflict was resolved and by June 1943 the shop assistants had an organization of record. At Nchanga, they were more timid and decided to continue pressing all claims through the Labor Officer. ${ }^{5}$

In November, Labor Commissioner Hudson wrote the secretary of the Associated Chambers of Commerce in Ndola, indicating that recognition of these shop assistants' unions by individual members of the chambers was desirable. The secretary, Mr. B. C. Paice, replied that this was a territorial question, perhaps one for Government to air by way of a conference. Acting Labor Commissioner Stubbs called this an evasion, but got nothing further from Paice, apart from a re-

1 Ibid., s February r 943.

2 Ibid., is February, 9 March and 22 April 1945.

${ }^{3}$ Sec./Lab./45, October and 29 December 1942.

- A body frequently composed of elders or at least chiefly representatives who were supposed to deal with the manifold problems which township Africans wished to bring to Government, and explain the numerous points which administrators hoped to get across to Africans. They had nothing to do with the mines, had no police powers, were not traditional authorities but instead a sort of spokesman cum mouthpiece.

${ }^{5} \mathrm{Sec}$ /Lab./45, October and 29 December 1942. 
commendation that members investigate local unions. The first meeting arising from this I944 suggestion, however, was not held for two years. ${ }^{1}$

When shop assistants at Luanshya had considered striking, Labor Department men and the District Commissioner (Lt. Commander Thomas Fox-Pitt, later one of two European members of African National Congress and after retirement from the Colonial service, secretary of the Anti-Slavery Society, until his recent venture to Algeria for the UK United Nations Assembly) advised them to seek a minimum wage inquiry instead. This displeased the Provincial Commissioner, who thought Fox-Pitt had been indiscreet, but the Secretary for Native Affairs did not see the harm in his remarks. When the shop assistants actually organized about 300 men and reached an agreement with both European and Indian shop keepers, the Labor Commissioner rejoiced, seeing in this a start towards collective bargaining. $^{2}$

In Kitwe, the assistants called themselves the African Shop Assistants' and Tailors' Committee, which first met on 8 November 1943, seeking higher piecework rates and a system of inclusive pay to avoid the complicated wages, fuel, food and housing allowance scheme generally in vogue, particularly in shops owned by Indians. ${ }^{3}$

Though these committees were not recognized by employers, they were not ignored. In May I944, the Chambers of Commerce complained that "African Labour Officers are encouraging employees to take their claims direct" to Government, a practice which undermined the good relations employers hitherto had enjoyed with their laborers. The Labor Commissioner indignantly denied that there were any "African Labour Officers" and wondered if it might be time for an inquiry into the wages and conditions of service in retail businesses. ${ }^{4}$

In September, a group of tailors struck for the first time, gaining a limited success against the Star Clothing Company of Livingstone, whose owner had been referred to Labor Officer Philpott by the police. These tailors were after a monthly contract, rather than the standard "ticket" of 30 working days. However, they accepted the

${ }^{2}$ Sec./Lab./3 I. Entire Shop Assistants' File.

2 Ibid., 9 May and 12 June 1946.

I Ibid., 8 November 1943. Typically, workers were paid by the piece, given the right to sleep in the shop, charged against work produced for this permission, provided food, which also was charged against production, given fuel or on occasion money in lieu of firewood, but in any case for an illiterate to keep abreast of charges was most unlikely. Workers usually pushed for commutation to wage payments and shop keepers normally resisted. One draws certain conclusions.

- Sec./Lab./3I, 4 and 9 May 1944. 
offer of another two shillings on the regular ticket, though Philpott was sure they would revive their original demand. Acting Commissioner Stubbs noted "progress towards collective bargaining by this class of employee". 1

One must not conclude that all officials agreed with the Labor Department approach. The District Commissioners of the Western Province, for instance, were on record in 1943 with the opinion that "no good purpose could be served by the United Kingdom Government sending labour representatives to the copperbelt". ${ }^{2}$ This seemed to put them in bed with those mining company managers whom the Labor Department accused of preventing the dissemination of collective bargaining information among boss boys. In the Department's view, refusal to impart trade union information encouraged the appeal of communist doctrine. ${ }^{3}$

Labor Department people were not the only ones to cause uneasiness. Missionaries, too, were suspected of a perverse interest in trade unionism; so much so, that the Labor Officer stationed in Ndola concluded "the Chamber of Mines might after all consider this Department as a lesser evil". The assessment seems to have been correct, for in August Commissioner Stubbs persuaded compound managers to let his officers provide basic instruction. Unfortunately, in October the Chamber of Mines hesitated, seeking to censor all lecture materials. Stubbs resisted. News of this qualification, he felt, would be taken badly by the Colonial Office. Stubbs hesitated to clash with the Chamber, but thought it likely "unless the Chamber is made to realise the true position". Labor Officer Law summed up the Department's attitude when he remarked that unless something were done soon, "we shall cut a very sorry figure before the next strike commission..."4

To a degree, the Chamber feared that an African union might become a powerful tool of the white miners. Government agreed. And, in fairness to the companies, government policy statements had not always been absolutely lucid. It was accepted that hitherto the Labor Department had been supported, but "the ultimate and inevitable goal of African trade unionism has never been plainly accepted". On the day this was written, the Department was told that Govern-

${ }^{1}$ Ibid., I 8 and 29 September 1944.

${ }^{2}$ Sec./Nat./86, Vol. II, Ndola, March 1943.

3 See Sec./Misc./73 for John Meshack Chamalula, who in 1946 was attending a trade union course offered by the Communist Party in Johannesburg.

-Acc. 52/17. Memo of 19 April 1943 on "Boss Boy Associations and Representation Generally", also entries for 13 August, 26, 28, and 30 October, 29 November and I December 1943. 
ment would support development along the right lines, where the workers were ready; where they were unprepared, no undue encouragement would be given. This seemed to lack precision. ${ }^{1}$

Impetus next was furnished by a minor civil servant, Mr. A. H. Elwell, who on I4 January 1946 addressed the annual general meeting of the Kitwe African Society, a successor to one of the welfare associations which African clerks and assistant teachers had organized in the towns during the 1930's, most of which withered during the long depression. Elwell, the first Social Welfare Officer on the copperbelt, was not quoted in the minutes (part of the subsequent difficulty), but according to the headmaster of Wusikili School, he had said that the 1935 and 1940 strikes had degenerated into riots because there was no controlling union. He thought the recent organization of African railway workers in Southern Rhodesia instructive, and speculated about the emergence of political parties from such bodies. The District Commissioner was furious at this undermining of his authority, as he construed Elwell's remarks, and recommended that the rash young man do a bush tour to learn repentance. Elwell was transferred to Livingstone on 4 February. The general secretary of the Society, one Jason Achiume, was dismissed from his post with the township management board, but the incoming president, Godwin Akabiwa Mbikusita Lewanika, who had been its rather unpopular secretary until i944, escaped censure. ${ }^{2}$

The Provincial Administration could object to Elwell's comments, but they were silent when the subject was raised by the senior unofficial member of Legislative Council, Colonel Sir Stewart Gore Browne. On 7 March 1946, he inquired whether a suitable advisor for African trade unions could not be found. A month later he was answered indirectly in a memo drafted by Mr. M. A. Bevan, who was out on secondment from the United Kingdom Ministry of Labour. Bevan argued that as Africans had not formed a stable work force, there was little demand for a union. He thought boss boys' associations a good thing, though of limited potential, and pointed out the unfortunate fact that the position of Labor Officers was determined largely "by the nature of their personal relations with the compound manager". A bit later, in the second week of May, he suggested the formation of works committees composed of tribal representatives and boss boys from all departments. These committees, advised by Labor Officers, would formulate worker demands, occasionally going over the heads

1 Ass. 52/17, memo of 28 December 1943 and notes of 22 April 1944.

${ }^{2} \mathrm{Sec} . / \mathrm{Nat} . / 3$ I I and Sec./Nat./448, is November 1945. Curiously, until the last year of the war, neither boss boys nor tribal representatives thought of industry-wide groupings. Sec./Lab./45. 
of compound managers to bring complaints to the mine supervisors. ${ }^{1}$

Bevan's memo interested Governor Sir John Waddington, who felt he would be questioned about the industrial color bar when he visited London. Sir John believed nothing would be gained by further discussions with the European miners. The only person who could impress them was a British trade unionist able to convey the trend of world opinion. He was persuaded that the visit of an anthropologist would inflame the white workers.

In London the Bevan proposals were discussed by the Secretary of State, representatives of the mining companies, the Governor and two unofficial members of Legislative Council, Gore Browne and Welensky. In October a draft was produced, in which the Secretary of State proposed to appoint a trade union specialist to the Labor Department. This was put to the Chamber of Miners on 28 October, but nothing could be learned from that quarter till the managing directors convened in Johannesburg in November. Then Sir Ernest Oppenheimer became ill and the indisposition of this colossus prevented serious discussion of native labor policy. Government was not deterred from announcing what in any case already was common knowledge in the clubs and bars of the copper towns. At the opening of the new session of Legislative Council a day after the planned Johannesburg conference, Sir John said that the formation of African trade unions was an ultimate goal of Government. The companies preserved silence, but Mr. Stubbs thought the Chamber grew harder to deal with at year's end. ${ }^{2}$

In mid-February, 1947, Chamber representatives met at Government House to discuss the London paper. In return for accepting that Africans had the right to approach general managers, the companies were assured that Government had no intention of publicizing this diminution of foremen's authority. And it was agreed that tribal representatives and boss boys' committees should be convened jointly for further discussions leading to the formation of a common body. In general, management hoped to preserve the tribal representatives, in some instances by insisting that they also be boss boys, in

\footnotetext{
${ }^{1}$ Sec./Lab./125 and Acc.52/17, I3 May 1946. Bevan's harsh summary of the African position perhaps should be in the record for the benefit of those who thought the entire Labour Government naively pro-African. He found Africans had "no settled occupation, no civic sense, no community of interests as workers, no real understanding. There can be little doubt that the tendency would be for trade unions to be started as personal enterprises conducting their affairs without any sense of responsibility or leadership in the true sense of the word, and exercising no real control or authority."

${ }^{2}$ Acc. $52 / 18$ and Sec./Lab./x25.
} 
others by insisting that they not be. Works committees of sorts did appear and by July the Department pronounced that the experiment was working well. No one pressed for the next stage, the formation of genuine trade unions. ${ }^{1}$

In fact, the miners stuck at this point, and it was the shop assistants who developed the first African union under the guidance of the newly-arrived trade union specialist, Mr. William S. Comrie. In late October, the Lusaka African Shop Assistants decided to convert their interim committee into a permanent body. (Comrie already had suggested this course in a speech which attracted unfavorable notice from the police Special Branch. ${ }^{2}$ By the first week of November, the Kitwe Association of shop assistants called for an all-copperbelt conference; within a month, Comrie was instructing five branches. However, the union was considered to date from 6 January 1948. Negotiations with the European chambers of commerce began in May, and by September reached a successful conclusion. By June 1949, even the Indian chambers had signed agreements, leaving Broken Hill alone outside the compact. ${ }^{3}$

This development, Government's announcement of its intentions and the arrival of the energetic Mr. Comrie all persuaded the European miners to revive the wartime notion of African branches under white tutelage. Union President Mr. Brian Goodwin, also a member of Legislative Council, had said in the Council Chamber that in this respect his organization set "a shining example". No one could shake Goodwin's belief that his miners had acted long before Government ever thought of doing so. To make themselves quite clear the union executive let it be known that the Labor Commissioner's persistence

${ }^{1}$ Ibid., 18 February 1947; Acc. 52/19, 17 March 1947; Sec./Lab./175.

${ }^{2}$ Sec./Lab./1 25, 30 October 1947; Sec./Lab./31, 29 October 1947; Acc. 52/19, 29 September 1947. Two years later the Labor Department decided its members "should studiously avoid conveying the impression to the public that they have adopted the 'security approach' of the Police towards labour problems, that they regard workers' organizations as potentially criminal or spy upon them, or that they use other than direct, open approach". Copperbelt Labor Officers were unhappy about the police "almost creating scares of industrial unrest". Box $419 . \mathrm{Ha} / \mathrm{I}$, Kitwe, 16 September 1949 . It appears that the mines were considered as discrete universes and that the various tribes employed on them retained their identity far longer, perhaps because far larger numbers of tribesmen congregated there than in the townships of Lusaka and Livingstone. Too, the mines initially trained up far fewer white collar types. The whole ethos of violence and self-help militated against a feeling of solidarity. Where shop assistants might combine, miners tended to brawl away their resentments in beerhalls.

sec./Lab./31, 3 November 1947; Sec./Lab./126, November 1947; EA 5I, Vol. I, 13 November 1947. Later stages of the story ate less pleasant to record. By 1950, it had organized clerks, coming by 1954 to be known as the African Shop, Distributive and 
"in the formation of African unions" would be met by union counteraction aimed at "anything the Africans had set up already". 1

This threat perplexed the Labor Department, which had been more concerned with management's reactions. Mr. Stubbs wanted a forward policy and asked his officers to explore all aspects of this tangle. That Government did not have a very definite policy is clear from his remark to the Senior Labor Officer in Kitwe that "any information you can get from other Labour Officers or compound managers without disclosing the fact that Government is attempting to formulate a policy would be interesting and should be kept until your visit here". 2

Executive Council was told that a new set of European wage demands might have something to do with this talk of African branches, but advised that certain other factors had to be considered, too. After all, Government had pronounced in favor of African unionism and Mr. Goodwin had gone to the Prague meeting of the World Federation of Trade Unions, where a resolution favoring equal pay for equal work had been adopted, "which would be a useful parrot cry with which to attract the more thoughtless Africans". (Some few might have agreed with Chamalula who wrote from Johannesburg about "this wonderful gift from those progressive European workers", ${ }^{3}$ but the African mineworkers' majority demonstrated early in January following that their faculties had not been impaired by lengthy exposure to Marxist analytical techniques.) Another factor to consider was the role of the British trade union movement, which naturally would sympathize with the white miners, as would anyone "were it possible to place any reliance on the good intentions of the union concerned". Bearing all this in mind, the Labor Commissioner in mid-December notified his officers that when seeking African views "it would not be unfair to point out that so far their interests and those of the European workers are not entirely in accord". 4

Allied Workers' Union, based on Ndola. As late as 1957 the Registrar of Unions had not received a copy of their constitution and in April I958 they were advised to disband and reform. Their finances were in confusion, their officials in politics, and they remained unregistered. In May the Registrar threatened to take action if they contravened the regulations covering unregistered unions. In October he refused them registration, which meant they had to dissolve within six months. A final reference to them in December I 960 describes them as deregistered, which is somewhat confusing. See Ja/3.

1 Sec./Lab./125, 13 June 1948.

Acc. $52 / 17,30$ December 1947.

${ }^{3}$ See the African Weekly for 4 February 1948.

- J 4 52/20, 24 November and 17 December 1947. 
Just before New Year's 1948, Messrs Law, Carter and Comrie of the Labor Department met with Mufulira management. In this session, Comrie, who regarded works committees as a transitional device, perceived that the Chamber of Mines thought of them as a means of forestalling Government-inspired unionism. For reasons which differed drastically from Comrie's, they agreed that works committees might be encouraged. Unfortunately, the Africans had no interest, now that unionism was in the air. ${ }^{1}$

Goodwin's threat of dual unionism was answered by Africans before Government had a chance to respond. On I4 January, Goodwin revealed that he was going to start with underground men at Nkana. He denied there was any real opposition, except from clerks such as Godwin Lewanika, whom he dismissed as company supporters. He also announced his intention of going to one of Comrie's meetings. But, he was ejected by the Africans, whose conduct suggested they were alive to the threat of Goodwin's offer. Comrie concluded it was too late to set up works committees. ${ }^{2}$

When it did act, Government proved firm. Publicity was given to the Shop Assistants' Union, whose formation was considered timely. ${ }^{3}$ And on 23 January at a further Government session a hard line was adopted. Mine managers would be invited to cease obstructing African efforts, for instance by ordering compound managers to stop propagandizing against unions. And the companies would be expected to recognize a union, whether or not a works committee existed on a particular mine. 4

On the last day of January, Goodwin told some Africans at Kitwe that any union Comrie set up would be company-dominated and used only to depress the level of European wages. He again instanced his attachment to the principle of equal pay for equal work as proof of his desire for African advancement, and ended by inviting his auditors home to tea, which caught the attention of cynics. ${ }^{5}$

This speech prompted yet another Government House meeting, at which Goodwin reiterated his plan for parallel African branches. He evidently thought that Government-inspired company unions

1 Sec./Lab./125, 16 and I9 January 1948.

${ }^{2}$ Ibid., 14 and I6 January 1948; J 4 52/20, 13 January 1948.

${ }^{3}$ Sec./Lab./125, meeting of 22 January 1948.

${ }^{4} \mathrm{Sec} / \mathrm{Lab} . / \mathrm{r} 26$, Comrie's reports of November 1947 and July I948; J 4 52/20.

${ }^{5} \mathrm{Sec} . / \mathrm{Lab} . / 126,3$ I January I 948 ; J 4 52/20, I2 February 1948. Since little sympathy is accorded the European mineworkers today, perhaps reference to the effect of one of Comrie's moral arguments is in order. Though I cannot measure it, I believe his charge that the union and certainly not management had an obligation to assist in the birth of an African union took effect in the minds of Mr. Goodwin and others on the executive body. 
were the only alternative. Indeed, he later charged that the record, which mentioned a third possibility, independent black unions, had been altered by Government. Goodwin was mild by comparison with Mr. F. S. Maybank, the union's general secretary, who was certain that the Labor Department was a front for the copper companies. ${ }^{1}$ The official response to these charges was an insertion of denials in the widely circulated Bulawayo Cbronicle, a newspaper often used for such purposes. ${ }^{2}$

In this strained atmosphere, the Anglo-Belgo-French official conference on colonial labor problems opened in Nigeria. Originally, Northern Rhodesia's delegate had been asked to prepare a paper on, among other related matters, African trade unions. Though the Protectorate's Governor had proposed that such topics be placed on the agenda, once he was embroiled with the European miners and the companies, he argued that such an essay would be more useful if originating in "a territory without the racial complications prevailing here". The Secretary of State agreed that some east African dependency should be approached, but in the event this brought cold comfort to the white miners, for the conference agreed that the formation and encouragement of African unions was very important. ${ }^{3}$

Probably because Kitwe was the town where white miners first tried to influence Africans against independent unionism, it was also the place where African miners first developed a union. Before the end of 1948, over 5,000 men had signed up at Nkana, and Government had admitted a willingness to recognize a supra-mine body, should the unions desire one. Some officials even foresaw a joint industrial council for the copperbelt. ${ }^{4}$

The unions grew most unevenly, but were accepted as viable by the summer of 1949 , which inaugurated an era of lightning strikes, themselves proof of discipline and influence. Recognition of this mass organization came on 9 August. For some years it waged war against tribal representatives, and in March 1953 , despite Government support for the office, men on the four principal mines voted overwhelmingly to abolish it. In the following year miners, drivers, shop assistants and general laborers met to discuss the next level of unionism, a territorial organization. Comrie, who approved the idea, attended. Recognition

${ }^{1}$ Sec./Lab./84, Vol. II, 3 February and letters of 4 March 1948.

${ }^{2}$ Sec./Lab./125, Executive Council meeting of 16 February 1948 and Bulawayo Chronicle, 2o February 1948.

${ }^{3}$ Sec./Lab./125, 16 February I 948.

${ }^{4}$ Box 432, N/2709/I; ZA 51, Vol. I, 22 November 1948. 
was postponed until the following year, however, the Colonial Office being notified on 17 October. ${ }^{1}$

By the mid-I950's, the secretary of the European union reported in despairing tones that "we appear to be fighting a losing battle. Public opinion overseas appears to be against us; and on the home front the Press is ever ready to hurl bitter criticisms at our heads. Ours appears to be the lost cause and we are pictured as the aristocrats of labour resting on the backs of the African working at slave rates."2 In 20 years the white miners passed from an assumption of permanent indispensability to despairing acceptance of the new world acoming, in which not only Africa, but its copper mines as well, would become the birthright of Africans.

In retrospect, progress towards trade unionism looks remarkably steady, with the goal reached in about a decade. Indeed, the events of I 947 and early 1948 virtually marched from the wings on cue. But, as conversations with participants have shown me, the reality was altogether different. Many generalizations have been drawn from this history, few seem warranted. Company reluctance, European worker recalcitrance, African insistence, all have been used as themes, and for those who find history a series of conspiracies, a succession of objectively determined clashes, or a grand march towards the present, this essay may be useful. Those without these props, however, may conclude with me that without some remarkable men in the Labor Department, the course of Northern Rhodesian industrial relations might have taken a very different and far more unhappy turn in the 1940's.

I See A. L. Epstein, Politics in an Urban African Community (Manchester, 1958), pp. 98-1or; C/1820/I, Vol. II, 28 May 1957; C/1808/I, Vol. I; Acc. 52/19, 15 June 1950. Also P. K. Lomas, "African Trade Unionism on the Copperbelt", in: South African Journal of Economics (June 1958).

C/1820/1, Vol. II. NRMWU annual report, p. 29 (1956). 